Proc. Estonian Acad. Sci. Geol., 2006, 55, 4, 296-320

\title{
Holocene buried organic sediments in Estonia
}

\author{
Leili Saarse, Jüri Vassiljev, Avo Miidel, and Eve Niinemets \\ Institute of Geology at Tallinn University of Technology, Ehitajate tee 5, 19086 Tallinn, Estonia; \\ saarse@gi.ee,vassilje@gi.ee,miidel@gi.ee, even@ut.ee \\ Received 13 February 2006, in revised form 18 May 2006

\begin{abstract}
An overview of 85 sites of Holocene buried organic sediments in Estonia is presented. This number includes 45 sites of pre-Ancylus and Ancylus age, which were buried during the Ancylus transgression, 31 sites of pre-Litorina and Litorina age, buried under Litorina transgression sediments, and 9 sites formed after post-Litorina time and mostly covered by aeolian sand. According to radiocarbon dates, the Ancylus Lake transgression started about $9500 \mathrm{yr}$ BP (10 $800 \mathrm{cal} \mathrm{BP})$, and culminated several hundred years later. Around $9000 \mathrm{yr}$ BP (10 $100 \mathrm{cal}$ BP) a rather rapid regression followed. Its magnitude reached up to $30 \mathrm{~m}$ in the areas of rapid uplift. Pollen spectra of these beds are characterized by a high frequency of Pinus pollen, which seems to be typical of the coastal waterbodies of this age and confuses determination of their Preboreal age. ${ }^{14} \mathrm{C}$ dates of Litorina buried beds differ considerably. We have evidence that the Litorina transgression started about $7500-7000$ yr BP (8300-7800 cal BP) and culminated at different times in different regions. Pollen spectra of Litorina buried organic strata vary considerably between sites; however, their Atlantic age is easily discernible. The simulated isobases of the Ancylus Lake and Litorina Sea shorelines and organic beds showed discrepancy in the surroundings of Pärnu and Narva bays.
\end{abstract}

Key words: buried organic sediments, ${ }^{14} \mathrm{C}$ dates, Ancylus Lake, Litorina Sea, Estonia.

\section{INTRODUCTION}

Buried organic sediments along ancient seacoasts offer a good possibility for dating transgressions and regressions of the Baltic Sea. Regressive phases brought about isolation of coastal lakes and lagoons, which due to land uplift became shallow, paludified, and during the following transgression were coated by waterlaid deposits. In buried conditions patches of peat and gyttja were sealed and preserved up to the present, offering material for radiocarbon dating. As such peat and gyttja lenses were formed during a relatively short time and later compressed 
by overlying minerogenic deposits, their thickness is commonly less than $50 \mathrm{~cm}$, rarely exceeding $100 \mathrm{~cm}$.

Hausen (1913) and Thomson (1933) reported the first evidence on the occurrence of buried organic deposits of Holocene age in Estonia. Hausen (1913) mentioned soil below the Ancylus sand and gravel at Piirsalu, Thomson $(1933,1937)$ described buried peat on the banks of the Pärnu and Narva rivers. Kents (1939) presented material on 37 sites with different beach formations and in 174 occasions adjusted their elevation. He proposed an idea of two transgressions of the Litorina Sea and their diachroneity in Estonia. In the 1960s, Helgi Kessel (Photos 1, 2) studied the Baltic Sea coastlines with biostratigraphic methods (pollen, diatom, and molluscs) and combined those with radiocarbon and archaeological approaches to justify the different stages of the Baltic Sea and their ecology on a firmer ground. In 1960, ten localities of Holocene buried organic sites were known: Jälgimäe (Thomson 1933), Päärdu (Laasi 1937), Kallavere, Jõelähtme, Võidu, Järise, Mustajõe (later renamed as Sikaselja), Piirsalu, Laitse, and Vakalepa (Kessel 1960; Fig. 1a; Appendix 1). Eight years later Kessel (1968) described already 38 sites with buried gyttja and peat, most of them found during the exploitation of gravel pits and mires. This year Helgi Kessel (21.06.1926-17.12.1989) would have celebrated her 80th birthday and on this occasion we decided to create and publish

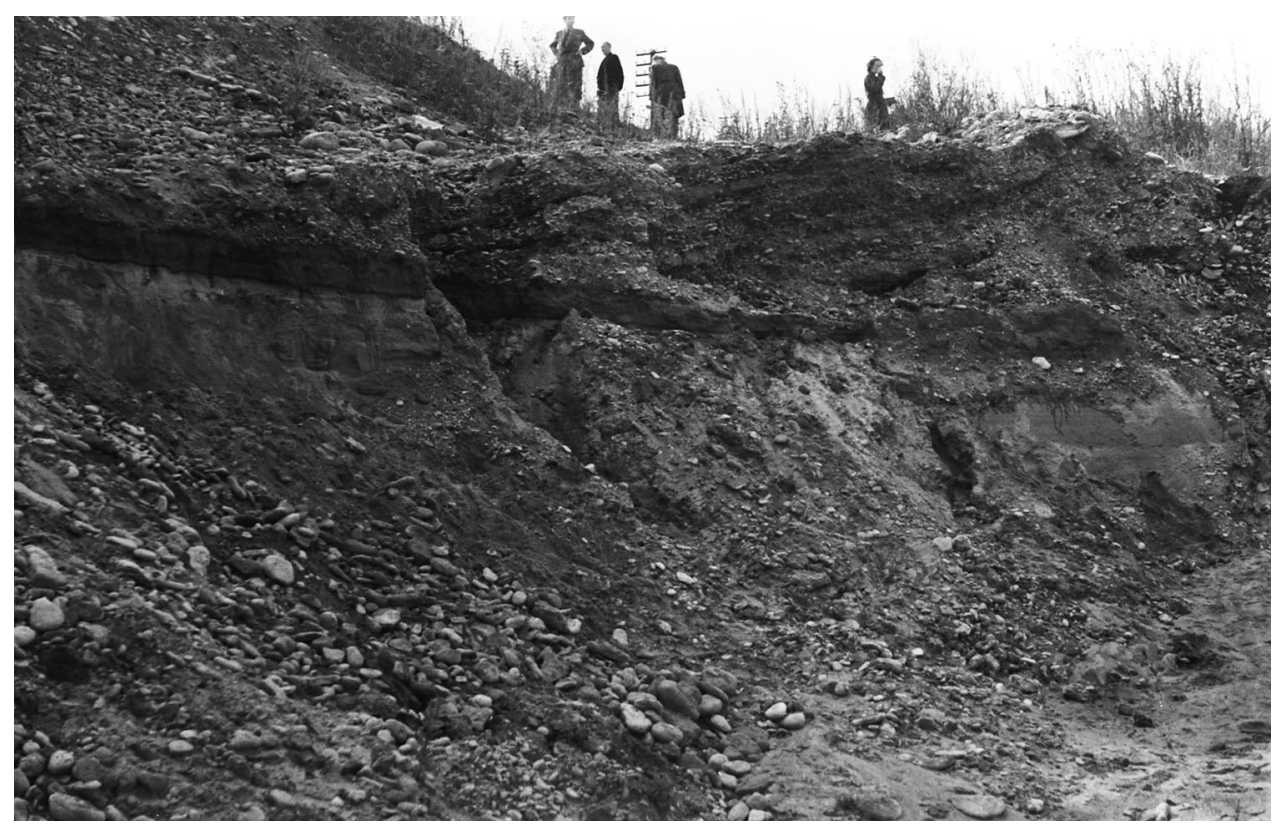

Photo 1. Buried organic bed, $20 \mathrm{~cm}$ thick, outcropping in Iru gravel pit (year 1958). Photo by A. Miidel. 


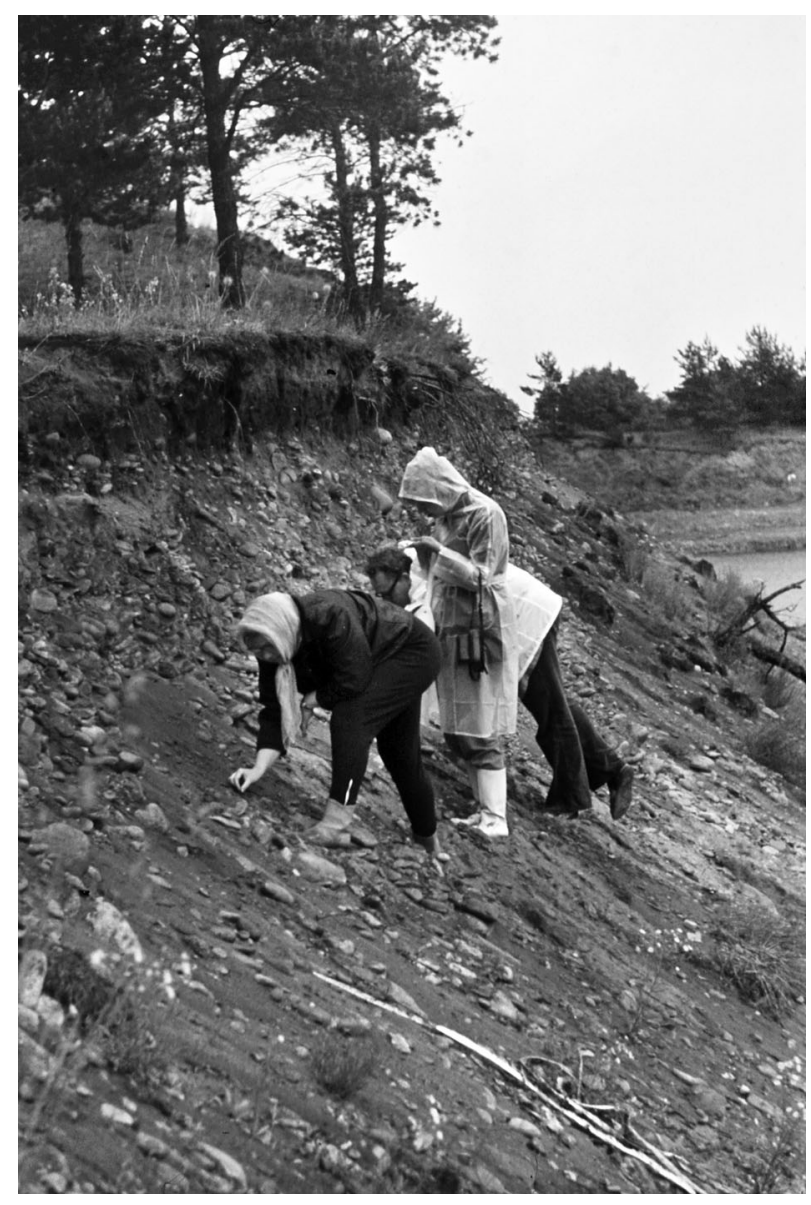

Photo 2. H. Kessel with Swedish colleagues U. Miller and L.-K. Königsson collecting Ancylus mollusc shells from Pärnamäe gravel pit in 1971. Photo by A. Miidel.

Fig. 1. (a) Location of pre-Ancylus and Ancylus buried organic sediment sites in Estonia with indication of the radiocarbon dated and not dated sites. 1, Sininõmme; 2, Kolga (Juminda); 3, Muuksi (Uuri); 4, Kahala; 5, Jõelähtme; 6, Kallavere; 7, Kroodi; 8, Lake Maardu; 9, Iru; 10, Merivälja; 11, Lake Ülemiste; 12, Jälgimäe; 13, Allikaküla (Laitse); 14, Põlluotsa; 15, Valgejärv; 16, Mustjärv; 17, Piirsalu; 18, Palivere; 19, Kullamaa (Kurisoo); 20, Ohtla; 21, Tapu; 22, Altküla; 23, Vakalepa; 24, Tagapere; 25, Oara; 26, Kastna; 27, Lake Ermistu; 28, Kõpu; 29, Lõpe; 30, Pressi; 31, Kõdu; 32, Urge; 33, Pulli; 34, Sindi; 35, Paikuse; 36, Sindi-Lodja; 37, Sikaselja; 38, Võidu; 39, Lemmeoja; 40, Pelisoo; 41, Tõrise; 42, Kasesoo; 43, Pitkasoo; 44, Järvesoo; 45, Siplase. (b) Location of pre-Litorina and Litorina buried organic sediment sites in Estonia with indication of the radiocarbon dated and not dated sites. 46, Tõrvala; 47, Leekovosoo; 48, Uuri (Maarikoja); 49, Mädajärve; 50, Kroodi; 51, Vahiküla; 52, Niitvälja; 53, Keila-Joa; 54, Kuijõe; 55, Väike-Lähtru; 56, Vigala; 57, Kirbla; 58, Tuudi; 59, Järise; 60, Kolga; 61, Seliste; 62, Jõõpre; 63, Oara; 64, Malda; 65, Audru; 66, Sindi; 67, Paikuse; 68, Sindi-Lodja; 69, Vaskrääma; 70, Rannametsa; 71, Jõempa; 72, Kärla; 73, Kihelkonna; 74, Vesiku; 75, Reo; 76, Lumiste. 

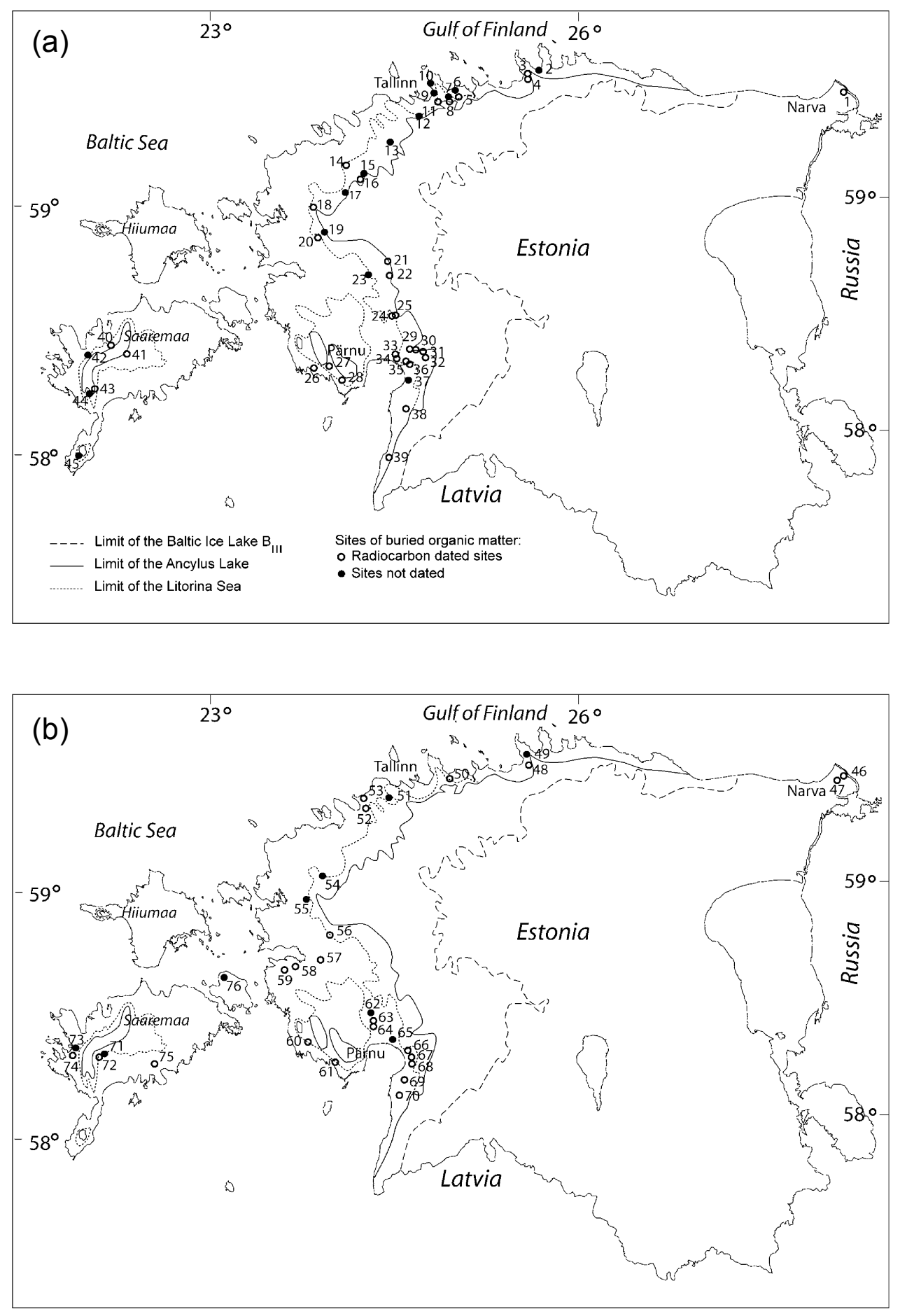
a database of Holocene buried organic sediments. In addition to all sites described by her, we have included in it several recently discovered sites. Up to now, this material was scattered in different publications and manuscripts. To fulfil this task, we collected and examined critically all the material available.

\section{MATERIAL AND METHODS}

To date, buried organic deposits of Holocene age are known from 85 sites. Of those, 45 are connected with the Ancylus Lake beach formations, 31 with the Litorina Sea, and 9 are younger and of various age. The compiled database of the Holocene buried organic deposits is presented in Appendixes 1-3. It includes radiocarbon-dated and undated sites, their coordinates, elevation, calibrated and uncalibrated ${ }^{14} \mathrm{C}$ dates, dated material, and references. All AMS ${ }^{14} \mathrm{C}$ dates were provided by the Ångström Laboratory, Uppsala University and are marked by the laboratory code Ua. Conventional radiocarbon dates were obtained at the ${ }^{14} \mathrm{C}$ laboratory of the University of Tartu (TA, Ta) and at the Institute of Geology, Tallinn (Tln). Radiocarbon dates were calibrated to calendar years using the Calib5.0 program at $1 \sigma$ confidence level (Stuiver \& Reimer 1993; Reimer et al. 2004). In the appendixes, the sites where pollen analyses have been carried out are marked with an asterisk. The location of the sites listed in Appendixes 1 and 2 is shown in Fig. 1. The reliability of the location and altitude of sites was checked using different sources of literature and topographic maps. Most elevations of sites were taken from the maps and are, therefore, marked with ca in the appendixes. Topographic maps indicate that some sites, reported as instrumentally measured, must have measurement errors, for example, Lõpe (Appendix 1) must lie about 2-3 $\mathrm{m}$ higher than reported. The database clearly shows that the elevation data are the most problematic and some extra work is required to improve the compiled database.

The shoreline displacement database of the Ancylus Lake and Litorina Sea was used to create water-level surfaces of the Ancylus Lake and Litorina Sea (Saarse et al. 2003a). The surfaces were compiled using a point kriging interpolation with linear trend approach (for details see Saarse et al. 2003a). The same approach was used to reconstruct the surfaces of buried organic sediments for two time intervals: $9500-8500$ and $8400-7000{ }^{14} \mathrm{C}$ yr BP. First, all the data falling into this interval were used to reconstruct water-level surfaces. Then the data visually not matching with sites nearby were eliminated and new water-level surfaces were compiled. After data elimination the time intervals narrowed to 9300-8600 and $8000-7000{ }^{14} \mathrm{C}$ yr BP. The top surfaces of the buried organic sediments were then compared with the water-level surfaces of the Ancylus Lake and Litorina Sea, respectively (Figs 2, 3). 

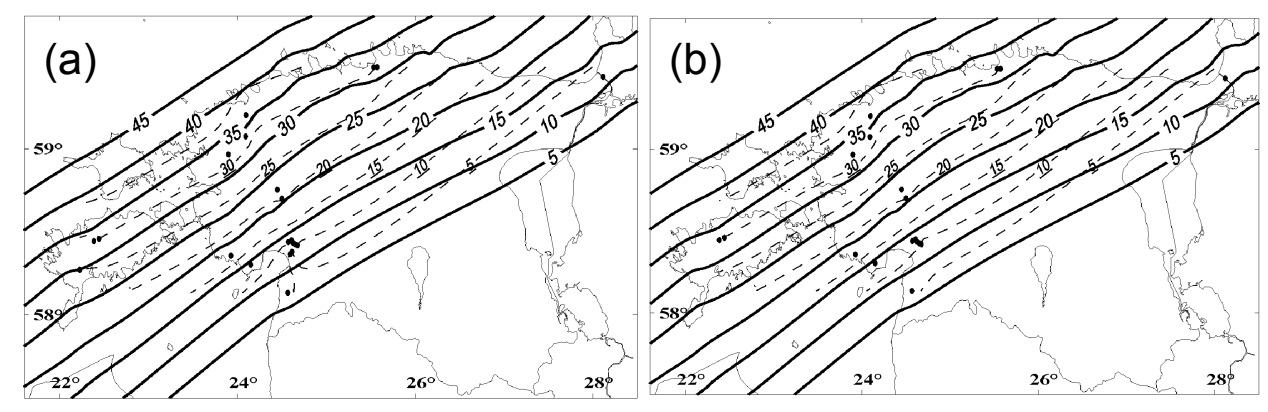

Fig. 2. (a) Isobases of the Ancylus Lake shorelines (solid line) and pre-Ancylus and Ancylus buried organic matter (dashed line) with indication of sites that were used in kriging point analyses. (b) Isobases modelled without sites 35 (Paikuse) and 36 (Sindi-Lodja) given in Appendix 1.
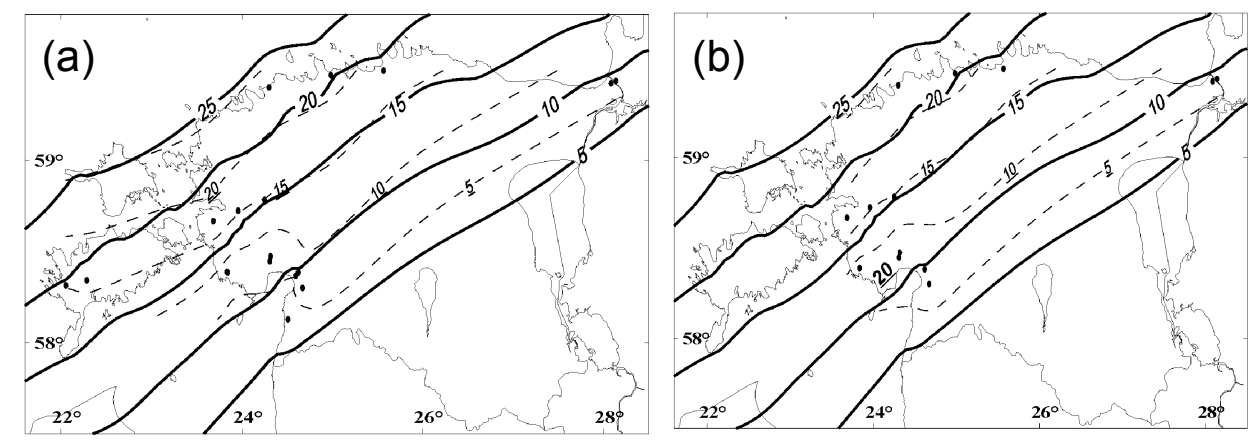

Fig. 3. (a) Isobases of the Litorina Sea shorelines (solid line) and pre-Litorina and Litorina buried organic matter (dashed line) with indication of sites that were used in kriging point analyses. (b) Isobases modelled without sites 68 (Sindi-Lodja), 70 (Rannametsa), and 72 (Kärla) given in Appendix 2.

\section{RESULTS AND DISCUSSION \\ Dating problems}

Radiocarbon ages of the organic deposits formed during Yoldia regression and Ancylus transgression (73 dates) vary significantly: from $8440 \pm 70$ (TA-263) to $9980 \pm 120$ (Tln-2349) at Jõelähtme (Appendix 1). The ${ }^{14} \mathrm{C}$ dates (50 dates) obtained for Ancylus regression and Litorina transgression deposits range from $5520 \pm 100$ (Tln-178) at Oara to $8400 \pm 190$ (Mo-222) at Kärla (Appendix 2). Post-Litorina buried organic beds have been found at nine sites. Their radiocarbon dates fluctuate

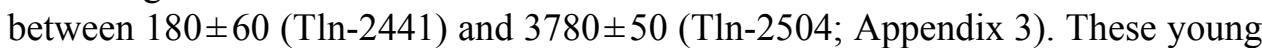
beds are mostly covered by aeolian sand. The variability of radiocarbon dates is caused by different factors. Firstly, in some places pre-Ancylus buried organic 
sediments contain deposits of both Yoldia regression and Ancylus transgression. In principal, the same is valid for the buried pre-Litorina beds, which can include the deposits of Ancylus regression and Litorina transgression. Secondly, radiocarbon dates depend on the material analysed (wood, seeds, bulk organic matter, insoluble or soluble fraction), its preservation and availability to weathering, contamination with older carbon or younger rootlets, hard water and reservoir effect, as well as the dating method used (Olsson 1986; Veski 1998; Wohlfarth et al. 1998; Olsson \& Kaup 2002).

Buried organic deposits from several sites, such as Jõelähtme, Ülemiste, Tapu, Kõdu, and Rannametsa (Fig. 1; Appendixes 1,2), have been newly examined and dated. Commonly, new conventional radiocarbon dates are older than those obtained earlier. At Jõelähtme the buried fen peat was earlier dated to 87008400 yr BP (Kessel \& Punning 1974). New dates obtained in 1997 indicate a considerably older age (Appendix 1), which is consistent with pollen stratigraphy (Veski 1998, p. 44). The same is valid for the Tapu organic deposits where the new ${ }^{14} \mathrm{C}$ date $(9325 \pm 65$, Tln-2185; Veski 1998) showed an older age than the earlier ones ( $8995 \pm 125$, TA-78 and $8460 \pm 180$, TA-75; Appendix 1). One and maybe the most important reason is the conservation of samples and the time span between collection and dating. For example, wood from the buried peat at Sindi (Appendix 2) was collected already in 1959 (Liiva et al. 1966), but analysed several years later and the age appeared to be $6710 \pm 110$ (TA-55). Comparison of conventional and AMS ${ }^{14} \mathrm{C}$ dates showed that in several cases AMS dates from seeds yielded younger ages than conventional radiocarbon dates from bulk peat, gyttja or wood. A good example is Lake Ermistu (Appendix 1), where woody fen peat at a depth of $520-530 \mathrm{~cm}$ was dated by the conventional ${ }^{14} \mathrm{C}$ method to $9515 \pm 120(T \ln -1378)$ and seeds from the midpoint of the same interval $(525 \mathrm{~cm})$ were dated to $8870 \pm 85$ (Ua-13031; Veski 1998).

\section{Geological setting}

The coastal formations of the Ancylus Lake are located at a height of $45 \mathrm{~m}$ a.s.1. on the Island of Hiiumaa, $13 \mathrm{~m}$ in Narva, and $5 \mathrm{~m}$ in SW Estonia near the Estonian-Latvian border (Fig. 2). The Litorina Sea shorelines occur at lower elevation. The highest Litorina limit has been registered at $25 \mathrm{~m}$ a.s.l. also on the Island of Hiiumaa, 21-22 m a.s.1. in NW Estonia (Thomson 1936; Kessel \& Raukas 1979), 9-10 m in Narva, and $5 \mathrm{~m}$ in SW Estonia (Fig. 3). Buried organic deposits are commonly located close to the Ancylus Lake and Litorina Sea transgression coastline, under beach ridges and spits where the sedimentation was rapid (Photo 1). Remarkable thickness (up to $1.3 \mathrm{~m}$ ) and spatial distribution of these deposits have been traced on the lower reaches of the Pärnu River, where more than 20 buried organic sequences are exposed on the river bank and its tributaries within a $40 \mathrm{~km}^{2}$ area (Veski et al. 2005). Here the height of preAncylus and Ancylus buried organic beds ranges between 3 and $16 \mathrm{~m}$ a.s.l. 
(Kessel 1963; Veski et al. 2005). In the Oara, Sindi, and Paikuse sequences two consecutive buried organic strata represent pre-Litorina and pre-Ancylus beds, respectively. At Pulli and Sindi-Lodja organic deposits are connected with the archaeological settlement sites.

Kessel (1968) divided the buried organic sediments in Estonia into two groups: (1) peat and gyttja, which deposited in terrestrial conditions and (2) reed peat and clayey gyttja, which accumulated in lagoons or bays. Peat and gyttja are enriched with green algae, insect remains, seeds, and other macroremains. Deposits of lagoons and bays are rich in mineral matter and contain few diatoms. The diatomite in Leekovo mire and Tõrvala is an exception, consisting almost entirely of diatomic frustules (Thomson 1937).

Buried peat was formed in two different ways. Firstly, due to rise in groundwater table, paludification, and overgrowing of relict lakes and lagoons isolated during the regression phases of the Baltic Sea. Such conditions seem to have existed at Ermistu, Sindi, Lemmeoja, and Pitkasoo where peat accumulation started before the Ancylus transgression, in the hollows and relict lakes on the Yoldia Sea terrace. Their pre-Ancylus age is confirmed by the pollen composition and radiocarbon dates. The basal part of buried peat is dated to $9850 \pm 165$ (Ua-13036) in Lake Ermistu, $9820 \pm 130$ (Tln-130) in Lemmeoja, and $9800 \pm 80$ (Ua-2285) in Pitkasoo (Appendix 1). Secondly, peat could have accumulated in the hollows and depressions due to water-level rise in the transgression phase. This seems to be the case at Kõdu where the swampy birch wood was drowned due to the rise in groundwater table. A question arises of how to differentiate the buried peat formed during the Yoldia Sea regression from that of the Ancylus Lake transgression if they occur in the same sequence. Commonly, the limit is placed along the lithological boundary between peat (regressional facies) and gyttja (transgressional facies), but if there is no clear lithological boundary, the limit between the Yoldia regressional and Ancylus transgressional bed is tentatively placed at $9500 \mathrm{yr}$ BP (10 $800 \mathrm{cal} \mathrm{BP})$.

The complete sedimentation cycle formed during the Ancylus transgression (from the beginning up to the culmination) can be followed in a few coastal lake sequences (Maardu, Ülemiste, Mustjärv, and Ermistu) and in some buried sequences (Põlluotsa, Lõpe, and Kõdu), which register the transgression event quite clearly. At Põlluotsa the basal sand is covered by woody peat, herbaceous-Hypnum peat, gyttja, lagoonal clay, and gravelly sand (Ploom et al. 1996). Woody peat accumulated in the conditions of groundwater table rise, and the Betula wood from it has been dated to $9350 \pm 70$ (Tln-2023). A similar transgressive sequence has been found at Kõdu, which starts with clay overlain by peat (9340 \pm 45 , Tln-1993), gyttja, silty sand, and sand (Raukas et al. 1999). The Lõpe sequence, where till beds are overlain by Phragmites peat, alternating lagoonal silt and sand, and covered by gravel, also refers to the transgressive nature of sediments (Raukas et al. 1995a). The age of the buried peat in the Lõpe sequence has been dated to $9215 \pm 70$ (Tln-1631) and 9260 \pm 70 (Tln-1632) (Appendix 1). In the Oara, Pulli, Sindi, and Paikuse sequences peat and gyttja are covered by alternating peaty and 
sandy layers, the origin of which has been interpreted differently (Raukas et al. 1999; Veski et al. 2005). At Skede Mose (Öland) such alternating sandy and gyttja layers have been interpreted as beds formed during the transgression maximum (Königsson 1968).

The Ancylus Lake culmination has been discussed and re-estimated recurrently. In the 1960s and 1970s it was suggested to have occurred between 8400 and 8200 yr BP (Kessel \& Punning 1969a; Kessel \& Raukas 1979), in the 1980s at about 8700 yr BP (Raukas et al. 1988), in the 1990s at 9000-9200 yr BP (Raukas et al. 1995b) or 9200-9300 yr BP (Saarse et al. 1997). The last mentioned ages are comparable to that suggested by Finnish and Swedish researchers (Berglund 1964; Eronen \& Haila 1982; Svensson 1989; Björck 1995; Berglund et al. 2005).

The reconstructed shore displacement curves suggest that the Ancylus Lake regressed rather rapidly (Kessel \& Raukas 1979; Björck 1995; Saarse et al. 1997; Berglund et al. 2005; Veski et al. 2005). The magnitude of the Ancylus Lake regression in Estonia varies from $30 \mathrm{~m}$ on the Island of Hiiumaa, judging by the low position of the Ancylus fauna (Raukas et al. 1996), to 11 or more metres in the vicinity of Pärnu (Veski et al. 2005), depending on the land uplift measure.

The development of the Litorina Sea was more complicated than that of the Ancylus Lake and opinions on the number of transgressions and timing of culmination vary considerably. Some authors have distinguished several transgressions in the history of the Litorina Sea (Kessel 1963; Kessel \& Raukas 1979; Sandgren et al. 2004; Berglund et al. 2005). Others have defined only one major transgression (Eronen 1974; Hyvärinen 1980; Kaland 1984; Hyvärinen et al. 1992; Seppä et al. 2000; Miettinen 2002). H. Kessel and A. Raukas later also supported the idea of one Litorina transgression (Kessel \& Raukas 1984; Hyvärinen et al. 1988). Lepland et al. (1996) studied the Narva area and tentatively distinguished there three transgression phases. It was explained with the circumstance that Leekovo lagoon had a limited connection with the sea and, therefore, could have been influenced by the water-level changes in the Narva River. In the Pärnu district, which lies on the same isobase as Narva, one Litorina transgression was recognized (Veski et al. 2005). Comparison of the shore displacement curves with the position of the settlement sites also supports the idea of one main transgression (Jussila \& Kriiska 2004; Veski et al. 2005).

The transitional stage between the Ancylus Lake and Litorina Sea is the Mastogloia Sea, or the Early Littorina Sea (Berglund et al. 2005), or Initial Litorina Sea (Andrén et al. 2000). Two periods have been distinguished in the history of the Early Littorina Sea: at $9800-9400 \mathrm{cal} \mathrm{BP}$ (8700-8300 yr BP) and 9400 8500 cal BP (8300-7700 yr BP), the last being known as the Mastogloia stage (Berglund 1964; Hyvärinen 1984, 1988). The first period established in Blekinge is characterized by diatoms, which show saline water inflow, but considerably earlier than previously assumed (Eronen et al. 1990). Deposits of the second period contain mainly freshwater diatoms. Beds of the first period are not known in Estonia, at least not of such an early age. The deposits of the Mastogloia period, recognized as a transitional diatom-stratigraphic unit, have been found at Tuudi, Lumiste (Kessel \& Pork 1974), Rannametsa (Hyvärinen et al. 1992), and Kõivasoo 
(Kents 1939; Saarse et al. 2000). The ages of the Tuudi (7860 \pm 70 , Tln-33; 85508850 cal BP), Rannametsa (8080 \pm 110 , Hel-2207A, 8770-9200 cal BP; $8060 \pm 110$, Hel-2207B, 8730-9130 cal BP), and Kõivasoo beds (8190 \pm 90 , TA-530; 9030 9260 cal BP) coincide with the time span of 9400-8500 cal BP suggested by Berglund et al. (2005). According to Kessel (1975), the Mastogloia stage in Estonia occurred later, at about 7600-7200 yr BP (8400-8100 cal BP).

It is hard to determine the start of the Litorina transgression on the basis of buried strata, because organic beds are poor in or completely lacking diatoms and molluscs, in contrast to the covering minerogenic beds, which comprise typical Litorina Sea taxa, e.g. Campylodiscus echeneis, Navicula peregrina, Diploneis interrupta. The beginning of the brackish Litorina transgression has been registered at about $8500 \mathrm{cal} \mathrm{BP}$ in southern Sweden (Berglund et al. 2005), and $8400 \mathrm{cal} \mathrm{BP}$ in the east of the Gulf of Finland (Miettinen 2002). A clearly brackish-water mollusc fauna of the Litorina Sea appeared in western Estonia about $7200 \mathrm{yr}$ BP or 7950-8150 cal BP (Kessel 1975).

The highest shoreline of the Litorina Sea in Estonia $(25 \mathrm{~m}$ a.s.l. on the Island of Hiiumaa) is dated to $7500 \mathrm{yr}$ BP (Königsson et al. 1998; $8150 \mathrm{cal} \mathrm{BP}$ ), whereas in the Narva area (10 m a.s.l.; Ramsay 1929) it is dated to ca $6600 \mathrm{yr}$ BP (7500 cal BP; Lepland et al. 1996). In the Pärnu area, which lies approximately on the same isobase as Narva (Fig. 3), the Litorina transgression culminated ca $6500 \mathrm{yr}$ BP or 7300-7400 cal BP (Veski et al. 2005). It means that in the areas of slower land uplift the transgression maximum occurred later than in the areas with more rapid uplift (Miettinen 2002) and that the highest Litorina level is diachronous (Hyvärinen et al. 1988).

The Litorina buried beds like those of Ancylus age are also represented by lagoonal clayey silt, gyttja or peat (Appendix 2). At Oara the pre-Litorina buried deposits are mostly composed of $135 \mathrm{~cm}$ thick Phragmites peat, underlain and covered by lagoonal clayey gyttja. The upper part of the gyttja was dated to $6100 \pm 50$ (TA-193). At Sindi, Paikuse, and Sindi-Lodja, the Litorina beds occur together with the Ancylus beds, forming the upper organic set (Kessel 1961; Veski et al. 2005). In several places (Kolga, Rannametsa, and Vesiku) the surfaces of buried beds have been subject to wave action and erosion. The traces of abrasion are visually observable.

\section{Pollen stratigraphy}

Pollen analyses show that the deposits formed during the Yoldia Sea regression (before $9500 \mathrm{yr}$ BP) are characterized by different pollen assemblages. Therefore it is hard to define their chronological position by palaeobotanical records only. Buried peat at Oara is dominated by Betula pollen, followed by Pinus (Kessel \& Punning 1969b). Pollen of Betula nana and Salix is continuously present, Alnus, Corylus, Ulmus, and Picea occur sporadically. The proportion of herbs is high on account of Poaceae and Cyperaceae. Typical arctic flora elements, such as Hippophä rhamnoides and Dryas octopetala, have been identified (Kessel \& Punning 1969b). In contrast to Oara, bottom peat in Pitkasoo and Lake Ermistu is 
enriched with Pinus pollen (Königsson et al. 1998; Veski 1998). The quantity of other tree pollen is negligible, even Betula pollen does not exceed $10 \%$.

Sediments deposited during the Ancylus transgression were examined palynologically at Jälgimäe, Põlluotsa, Tapu, Ermistu, Kõdu, Lõpe, Kõpu, Sindi, Paikuse, Võidu, Lemmeoja, Jõelähtme, and Pelisoo (Fig. 1a). They are characterized by the dominance of Pinus pollen, whose frequency fluctuates from 60 to $90 \%$. The amount of Betula is commonly between 10 and 30\%. Salix, Juniperus, Populus, Alnus, Corylus, and Ulmus are present sporadically or with low values. Among herbs, Poaceae and Cyperaceae are dominating. In lakes with continuous sedimentation, such as Ülemiste, Maardu, Mustjärv, and Ermistu, Betula pollen surpasses in frequency Pinus pollen (Saarse et al. 1997; Veski 1998) and the pollen assemblage is more similar to that of Preboreal age. The high Pinus percentages and sometimes considerably younger than expected ${ }^{14} \mathrm{C}$ age were the main reasons why in the 1960s and 1970s the Ancylus transgression was correlated with the Boreal chronozone (Kessel \& Punning 1969a; Kessel \& Raukas 1979).

Pollen assemblages of the Mastogloia beds (Lumiste, Tuudi) show the following frequencies: Pinus and Betula 30-50\%, Alnus 13-22\%, QM (Ulmus, Tilia, and Quercus) 4-10\%, Corylus 5-12\%. The pollen of Picea is low, less than 2\% (Kessel \& Pork 1974). Among other species in both lagoonal beds Campylodiscus clypeus, C. echeneis, and Mastogloia smithii have been identified (Kessel \& Pork 1974).

The pollen composition of the Litorina beds varies considerably from site to site. The pollen assemblages in buried sediments on the lower reaches of the Pärnu River are dominated by Betula, Pinus, and Alnus with herbs composed mainly of Poaceae and Cyperaceae (Thomson 1933; Kessel 1963; Veski et al. 2005). In several pollen diagrams (Vesiku, Kärla, Seliste) at first Pinus pollen dominates $(60-80 \%)$. It decreases upwards, directly corresponding to increase in Betula, Corylus, and QM. The Keila-Joa diagram displays equal pollen percentages (up to 30\%) for Betula and Alnus, 3\% for Picea, and 5\% for QM. Pollen assemblages at Kolga differ by a high proportion of Betula (30-60\%), at Seliste and Tõrvala by the prevalence of Alnus and Betula (up to 50\%; Kessel 1963; Kessel \& Punning 1969a). In the Kolga diagram QM reaches 10\%, Picea 1-2\%, and Corylus up to $20 \%$. All this shows that pollen assemblages differ substantially with sites and reflect the local vegetation composition, and determination of sediment position in the chronological scale can fail.

\section{Modelling results}

The isobases of the modelled water-level surfaces of the Ancylus Lake and Litorina Sea are presented in Figs 2a and 3a. The modelled Ancylus Lake shoreline shows that the isobases are almost straight lines, with some minor exceptions (Fig. 2a). The Ancylus Lake water-level surface is plane, tilted from northwest to southeast. It refers to even and regular uplift of Estonia at that time, without noticeable connection between isobases, bedrock geology, and tectonics. The simulated sea surface of the Litorina transgression shows a more complicated 
pattern (Fig. 3a). It appears that some Litorina isobases are not straight lines: in NE Estonia the $15 \mathrm{~m}$ isobase has a greater inclination in an easterly direction than previously suggested (Kessel \& Raukas 1979, 1984). Spacing between the Litorina isobases varies regionally, probably as a result of different land uplift and a non-contemporaneous Litorina transgression. In general, the modelling results (Figs 2a, 3a) are similar to those obtained earlier using trend-surface analysis (Miidel 1995).

Comparison of the Ancylus Lake water level with the isobases of the buried organic matter of Ancylus age (9500-8500 yr BP) shows discrepancies in the Pärnu area, especially at two localities - Sindi-Lodja and Paikuse (Appendix 1; Fig. 2). The organic matter of Ancylus age at Sindi-Lodja (9170 \pm 200, Ta-2784) and Paikuse (9575 \pm 90 , TA-2547) lies about 4-5 m lower than at the sites nearby. Both these sites are located on the riverbank where varved clays underlie the studied deposits and landslides are quite common, thus one can suspect that these deposits are not in situ position. Furthermore, it is not reasonable to rule out other possibilities, e.g., erosion at the beginning of the Ancylus transgression during which the upper part of organic layers could have been removed, or erroneous elevation of the buried organic beds, as several sections were not levelled. Simulation of isobases without Paikuse and Sindi-Lodja sites improved the modelling results significantly (Fig. 2b). In general, the buried organic matter lies slightly (about 1-2 m) below the modelled level of the Ancylus Lake, which indicates that it deposited before the Ancylus transgression. In SW Estonia organic matter lies about $4 \mathrm{~m}$ below the modelled level of the Ancylus Lake (Fig. 2b). The reason for such a phenomenon is not clear and more detailed studies are required.

Comparison of the water level of the Litorina Sea with the isobases of the buried organic matter (time span 8400-7000 yr BP) shows discrepancies in the same area around Pärnu Bay (Fig. 3a). Here landslides at Sindi-Lodja and erosion at Kolga and Malda (Fig. 1b) could have affected the geological setting of the buried bed. The low elevation of the Rannametsa buried bed (Appendix 2) does not match with the elevation of the other sites nearby. Simulation without SindiLodja and Rannametsa sites, but also Kärla which is much older $(8400 \pm 190$, Mo-222; Appendix 2), improved slightly the results, but the discrepancy around Pärnu still remains (Fig. 3b). In general, the buried organic matter is almost at the same elevation with the modelled level of the Litorina Sea above the $15 \mathrm{~m}$ isobase, but some metres lower below that isobase, which is hard to justify.

\section{CONCLUSIONS}

- The database of Holocene buried organic sediments of Estonia, including 85 sites, was compiled. The transgressional and regressional phases of the Baltic Sea created suitable conditions for the deposition of peat and gyttja, which during the transgressions were coated by minerogenous deposits of the 
Ancylus Lake and Litorina Sea. Such sites are now known in 76 localities. The post-Litorina buried peat (nine sites) is mostly covered by aeolian sand, not by marine one.

- Radiocarbon dates received on buried peat and gyttja differ considerably depending on the bedding conditions and material and methods used. In several cases, the ${ }^{14} \mathrm{C}$ ages obtained recently are older than earlier ones, possibly due to methodological reasons or mistakes at sample collection and preservation.

- Buried organic deposits of Ancylus age are mostly characterized by the dominance of Pinus pollen. This was the main reason why earlier the Ancylus transgression was connected with the Boreal chronozone, explaining also its 1000 years younger age compared to the results from Scandinavia.

- Comparison of shore displacement curves and the ancient settlement position does not support the opinion about the multiple Litorina transgression. We favour the idea that the Litorina transgression culminated at different times, first in the areas of rapid uplift.

- According to studies carried out in Estonia, the Ancylus transgression developed between 9500 and $9000 \mathrm{yr}$ BP (10 800-10 $100 \mathrm{cal} \mathrm{BP})$, while the Litorina Sea culminated between 7500 and $6600 \mathrm{yr}$ BP (8100-7400 cal BP).

- Simulation of buried organic matter beds and shoreline isobases shows discrepancies, especially in the surroundings of Pärnu Bay. This can mainly be explained by landslides.

- Detailed bio- and chronostratigraphic analyses are needed to register more precisely the beginning and end of transgressions, especially the character of the Litorina transgression.

\section{ACKNOWLEDGEMENTS}

This research was dedicated to the 80th birthday of our late colleague Helgi Kessel. We are indebted to H. Kukk for linguistic help. Special thanks go to $\mathrm{S}$. Veski and referees A. Raukas and M. Eronen for valuable suggestions and comments. The study was supported by the Estonian target financing project HM0332710s06 and Estonian Science Foundation (grant 6736).

\section{REFERENCES}

Andrén, E., Andrén, T. \& Sohlenius, G. 2000. The Holocene history of the southwestern Baltic Sea as reflected in a sediment core from the Bornholm Basin. Boreas, 29, 233-250.

Berglund, B. E. 1964. The post-glacial shore displacement in eastern Blekinge, southeastern Sweden. Sver. Geol. Unders., C599, 1-47.

Berglund, B. E., Sandgren, P., Barnekow, L., Hannon, G., Jiang, H., Skog, G. \& Yu, S.-Y. 2005. Early Holocene history of the Baltic Sea, as reflected in coastal sediments in Blekinge, southeastern Sweden. Quat. Int., 130, 111-139.

Björck, S. 1995. A review of the history of the Baltic Sea, 13.0-8.0 ka BP. Quat. Int., 27, 19-40. 
Eronen, M. 1974. The History of the Litorina Sea and associated Holocene Events. Soc. Sci. Fennicae, Comment. Phys.-Math., 44, 79-195.

Eronen, M. \& Haila, H. 1982. Shoreline displacement near Helsinki, Southern Finland, during the Ancylus Lake stage. Ann. Acad. Sci. Fenn. AIII, Geol.-Geogr., 134, 111-129.

Eronen, M., Ristaniemi, O. \& Lange, D. 1990. Analysis of a sediment core from the Mecklenburg Bay, with a discussion on the early Holocene history of the southern Baltic Sea. Geol. Fören. Stockholm Förhandl., 112, 1-8.

Haila, H. \& Raukas, A. 1992. Ancylus Lake. In Geology of the Gulf of Finland (Raukas, A. \& Hyvärinen, H., eds), pp. 283-296. Institute of Geology, Estonian Academy of Sciences, Academy of Finland, Helsinki University; Tallinn (in Russian).

Hausen, H. 1913. Über die Entwicklung der Oberflächenformen in den russischen Ostseeländern. Fennia, 34, 1-142.

Heinsalu, A. 2000. Diatom stratigraphy and palaeoenvironment of the Yoldia Sea in northern Estonia. Proc. Estonian Acad. Sci. Geol., 49, 218-243.

Heinsalu, A., Veski, S. \& Moora, T. 1999. Bio- and chronostratigraphy of the early Holocene site of double-storied buried organic matter at Paikuse, southwestern Estonia. Proc. Estonian Acad. Sci. Geol., 48, 48-66.

Hyvärinen, H. 1980. Relative sea-level changes near Helsinki, southern Finland, during early Litorina times. Bull. Geol. Soc. Finland, 52, 207-219.

Hyvärinen, H. 1984. The Mastogloia stage in the Baltic Sea history. Diatom evidence from southern Finland. Bull. Geol. Soc. Finland, 56, 99-115.

Hyvärinen, H. 1988. Definition of the Baltic stages. In Problems of the Baltic Sea History (Donner, J. \& Raukas, A. eds), Ann. Acad. Sci. Fenn. AIII, Geol.-Geogr., 148, 7-11.

Hyvärinen, H., Donner, J., Kessel, H. \& Raukas, A. 1988. The Litorina Sea and Limnea Sea in the northern and central Baltic. In Problems of the Baltic Sea History (Donner, J. \& Raukas, A., eds), Ann. Acad. Sci. Fenn. AIII, Geol.-Geogr., 148, 25-35.

Hyvärinen, H., Raukas, A. \& Kessel, H. 1992. Mastogloia and Litorina Seas. In Geology of the Gulf of Finland (Raukas, A. \& Hyvärinen, H., eds), pp. 296-303. Estonian Academy of Sciences, Institute of Geology, Academy of Finland, Helsinki University; Tallinn (in Russian).

Ilves, E., Liiva, A. \& Punning, J.-M. 1974. Radiocarbon Dating in the Quaternary Geology and Archaeology of Estonia (Serebrjannyj, L., ed.). Institute of Zoology and Botany, Institute of Geology, Academy of Sciences of the Estonian SSR; Tallinn (in Russian).

Ilves, E., Punning, J.-M. \& Liiva, A. 1969. Verzeichnis der im Institut für Zoologie und Botanik der Akademie der Wissenschaften der Estnischen SSR Mittels der Radiokohlenstoff-methode Datierten Proben IV. Eesti NSV Tead. Akad. Toim. Biol., 18, 417-426.

Jaanits, L. \& Jaanits, K. 1978. Ausgrabungen der frühmesolithischen Siedlung von Pulli. Eesti NSV TA Toim. Ühiskonnateadused, 27, 56-63.

Jussila, T. \& Kriiska, A. 2004. Shore displacement chronology of the Estonian Stone Age. Estonian J. Archaeology, 8, 3-32.

Kaland, P.-E. 1984. Holocene shore displacement and shoreline in Hordaland, western Norway. Boreas, 13, 203-242.

Kents, P. 1939. Postglatsiaalsed Läänemere rannajoone võnkumised Eestis illustreeritud Kõpu poolsaarel. Tallinn (unpublished report in Estonian State Archives).

Kessel, H. 1960. Holozäne Küstenbildungen der Ostsee auf dem Territorium der Estnischen SSR. Eesti NSV TA Geol. Inst. Uurimused, V, 279-303 (in Russian).

Kessel, H. 1961. Balti mere arenemisest Eesti NSV territooriumil Holotseenis. Eesti NSV TA Geol. Inst. Uurimused, VII, 167-185.

Kessel, H. 1962. Balti mere setete alla mattunud organogeensete järve- ja soosetete stratigraafiast Eestis. ENSV TA Geoloogia Instituut, Tallinn (unpublished report in Estonian State Archives).

Kessel, H. 1963. On the age of Holocene transgressions of the Baltic Sea in Estonia by palynological analysis. Baltica, 1, 101-115 (in Russian). 
Kessel, H. 1966. Joldiamere pinnavormid ja setted Eesti NSV-s. ENSV TA Geoloogia Instituut, Tallinn (unpublished report in Estonian State Archives).

Kessel, H. 1968. Mattunud soo- ja järvesetetest. Eesti Loodus, 1, 12-16.

Kessel, H. 1975. Läänemere geoloogiline areng hilisglatsiaalis ja holotseenis Eesti territooriumil. ENSV TA Geoloogia Instituut, Tallinn (unpublished report in State Archives).

Kessel, H. \& Linkrus, E. 1979. Ancient coastal lakes and coastal formations in the western part of Lahemaa. In Eesti NSV saarkõrgustike ja järvenõgude kujunemine (Raukas, A., ed.), pp. 104-117. Valgus, Tallinn.

Kessel, H. \& Pork, M. 1974. On the age of some coastal lakes of the Baltic Sea and the character of the diatom flora in west Estonia. Hydrobiological Studies, VI, 26-50. Institute of Zoology and Botany, Academy of Sciences of the Estonian SSR, Tallinn (in Russian).

Kessel, H. \& Punning, J.-M. 1969a. Über das Absolute Alter der holozänen transgressionen der Ostsee in Estland. Eesti NSV Tead. Akad. Toim. Keemia Geol., 18, 140-153 (in Russian).

Kessel, H. \& Punning, J.-M. 1969b. Über die Verbreitung und Stratigraphie der Sedimente des Joldiameers in Estland. Eesti NSV Tead. Akad. Toim. Keemia Geol., 18, 154-163 (in Russian).

Kessel, H. \& Punning, J.-M. 1974. About the age of the Ancylus stage in Estonia (radiometric datings). Eesti NSV Tead. Akad. Toim. Keemia Geol., 23, 59-64 (in Russian).

Kessel, H. \& Raukas, A. 1967. The Deposits of the Ancylus Lake and Litorina Sea in Estonia. Valgus, Tallinn (in Russian).

Kessel, H. \& Raukas, A. 1979. The Quaternary history of the Baltic, Estonia. In The Quaternary History of the Baltic (Gudelis, V. \& Königsson, L.-K., eds), Acta Univ. Ups. Annum Quingentesimum Celebrantis, 1, 127-146.

Kessel, H. \& Raukas, A. 1984. Correlation of the Baltic ancient coastal formations in Estonia and Sweden. Eesti NSV Tead. Akad. Toim. Geol., 33, 146-157.

Königsson, L.-K. 1968. The Ancylus transgression in the Skede Mose area, Öland. GFF, 90, 5-36.

Königsson, L.-K., Saarse, L. \& Possnert, G. 1998. The Pitkasoo Bog - an Ancylus lagoon from Saaremaa Island, Estonia. Proc. Estonian Acad. Sci. Geol., 47, 86-107.

Künnapuu, S. 1957. Pirita jõe alamjooksu genees. Eesti Geograafia Seltsi aastaraamat 1957, pp. 74-87. Eesti Teaduste Akadeemia, Tallinn.

Künnapuu, S. 1968. Esialgseid andmeid liivaga kaetud turbalasundite kohta Tallinnas. Eesti Geograafia Seltsi aastaraamat 1966, pp. 89-105. Valgus, Tallinn.

Laasi, A. 1937. Pinnaehitus. In Läänemaa geoloogia (Öpik, A. \& Laasi, A., eds), TÜ Geol. Inst. Toim., 51, 1-29.

Lepland, A., Hang, T., Kihno, K., Sakson, M., Sandgren, P. \& Lepland, A. 1996. Holocene sealevel changes and environmental history in the Narva area, north-eastern Estonia. In Coastal Estonia. Recent Advances in Environmental and Cultural History (Hackens, T., Hicks, S., Lang, V., Miller, U. \& Saarse, L., eds), pp. 313-358. Rixensart, Belgium.

Liiva, A., Ilves, E. \& Punning, J.-M. 1966. Data of the geo-biochemical laboratory of Institute Zoology and Botany Academy of Sciences Estonian SSR. In Upper Pleistocene. Stratigraphy and Absolute Geochronology, pp. 259-264. Nauka, Moscow (in Russian).

Linkrus, E. 1988. Suurekõrve reservaat. Pinnaehitus ja maastikuline struktuur. In Lahemaa uurimused III. Rahvuspargi looduse inventeerimine (Etverk, I., ed.), pp. 16-31. Valgus, Tallinn.

Lõokene, E. 1950. Laitse ja Märjamaa vahelise ala kvaternaarigeoloogia. Tartu Riiklik Ülikool, Tartu (unpublished diploma project in Estonian State Archives).

Männil, R. 1963. The fresh-water lime deposits of Saaremaa, their malacofauna and age. Eesti NSV TA Geol. Inst. Uurimused, XII, 145-161 (in Russian).

Männil, R. 1964. Järvelubjalasundite levik ja stratigraafia Eestis. ENSV TA Geoloogia Instituut, Tallinn (unpublished PhD thesis in the Institute of Geology TTU).

Miettinen, A. 2002. Relative sea level changes in the eastern part of the Gulf of Finland during the last 8000 years. Ann. Acad. Sci. Fenn. Geol.-Geogr., 162, 1-102.

Miidel, A. 1995. An attempt to apply trend-surface analysis to the study of raised shorelines of the Baltic Sea in Estonia. Proc. Estonian Acad. Sci. Geol., 44, 97-110. 
Olsson, I. U. 1986. Radiocarbon dating. In Handbook of Holocene Palaeoecology and Palaeohydrology (Berglund, B. E., ed.), pp. 273-292. Wiley \& Sons, Chichester.

Olsson, I. U. \& Kaup, E. 2002. On sources of errors by dating lake sediments, especially indicated by the varying radiocarbon activity of some recent water plants from Estonia. In European Society for Isotope Research, VI Isotope Workshop, pp. 74-75. Institute of Geology at Tallinn Technical University, Tallinn.

Orviku, K. 1936. Litoriina randvalli geoloogiast Kroodi oru kohal. Eesti Loodus, 2, 61-63.

Paas, A. 1960. Mullastikulisi märkmeid Audru jõgikonna saviliivade alt. Eesti Loodus, 1, 42-46.

Ploom, K., Kihno, K. \& Rajamäe, R. 1996. Põlluotsa - a new site of buried organic material in NW Estonia. (With some implications to the history of the Baltic Sea). In Geological History of the Baltic Sea. Abstract Volume of Field Symposium, pp. 61-62. Vilnius.

Poska, A. \& Veski, S. 1999. Man and environment at 9500 BP. A palynological study of an EarlyMesolithic settlement site in South-West Estonia. In Proceedings of the Fifth European Palaeobotanical and Palynological Conference (Stuchlik, L., ed.), Acta Palaeobot., supplement 2, 603-607.

Punning, J.-M., Rajamäe, R., Ehrenpreis, M. \& Sarv, L. 1977. Tallinn radiocarbon dates IV. Radiocarbon, 19, 111-117.

Punning, J.-M., Rajamäe, R., Joers, K. \& Putnik, H. 1980. Tallinn radiocarbon dates VI. Radiocarbon, 22, 91-98.

Ramsay, W. 1929. Niveauverschiebungen, eisgestaute Seen und Rezession des Inlandeises in Estland. Fennia, 52, 1-48.

Raukas, A., Kessel, H., Rajamäe, R. \& Heinsalu, A. 1988. On the development of the Ancylus Lake in the central Baltic. In Geology and History of the Baltic Sea and Formation of Mineral Resources (Raukas, A. \& Tavast, E., eds), pp. 73-76. Institute of Geology, Academy of Sciences of the ESSR; Tallinn (in Russian).

Raukas, A., Kimmel, K. \& Rajamäe, R. 1995a. A new site of buried peat at Lõpe, SW Estonia. Proc. Estonian Acad. Sci. Geol., 44, 133-137.

Raukas, A., Moora, T. \& Karukäpp, R. 1995b. Läänemere arengust ja inimasustusest Pärnu ümbruses. In Liivimaa geoloogia (Meidla, T., Jõeleht, A., Kalm, V. \& Kirs, J., eds), pp. 119123. Tartu.

Raukas, A., Tavast, E. \& Molodkov, A. 1996. Partsi - a new promising area for the investigation of Late Boreal and Early Atlantic water level changes of the Baltic Sea. Proc. Estonian Acad. Sci. Geol., 45, 92-101.

Raukas, A., Moora, T. \& Karukäpp, R. 1999. The development of the Baltic Sea and Stone Age settlement in the Pärnu area of southwestern Estonia. In Environmental and Cultural History of the Eastern Baltic Region (Miller, U., Hackens, T., Lang, V., Raukas, A. \& Hicks, S., eds), pp. 15-34. Rixensart, Belgium.

Reimer, P. J., Baillie, M. G. L., Bard, E., Bayliss, A., Beck, J. W., Bertrand, C. J. H., Blackwell, P. G., Buck, C. E., Burr, G. S., Cutler, K. B., Damon, P. E., Edwards, R. L., Fairbanks, R. G., Friedrich, M., Guilderson, T. P., Hogg, A. G., Hughen, K. A., Kromer, B., McCormac, F. G., Manning, S. W., Ramsey, C. B., Reimer, R. W., Remmele, S., Southon, J. R., Stuiver, M., Talamo, S., Taylor, F. W., van der Plicht, J. \& Weyhenmeyer, C. E. 2004. IntCal04. Terrestrial radiocarbon age calibration, 26-0 ka BP. Radiocarbon, 46, 1029-1058.

Saarse, L., Rajamäe, R., Heinsalu, A. \& Vassiljev, J. 1991. The biostratigraphy of sediments deposited in the Lake Kaali meteorite impact structure, Saaremaa Island, Estonia. Bull. Geol. Soc. Finland, 63, 129-139.

Saarse, L., Heinsalu, A., Poska, A., Veski, S., Rajamäe, R., Kihno, K. \& Martma, T. 1997. Early Holocene shore displacement of the Baltic Sea east of Tallinn (N Estonia). Baltica, 10, 13-24.

Saarse, L., Heinsalu, A., Karhu, J., Vassiljev, J. \& Veski, S. 2000. Holocene shoreline displacement and palaeogeography of the Kõpu Peninsula, Hiiumaa, Estonia. Baltica, 13, 15-23.

Saarse, L., Veski, S. \& Miidel, A. 2001. Lepistiku buried peat, Tallinn, Estonia. Proc. Estonian Acad. Sci. Geol., 50, 128-134. 
Saarse, L., Vassiljev, J. \& Miidel, A. 2003a. Simulation of the Baltic Sea shorelines in Estonia and neighbouring areas. J. Coastal Res., 19, 261-268.

Saarse, L., Miidel, A. \& Vassiljev, J. 2003b. The role of K. Orviku in the studies of the Litorina transgression in Estonia. In International Symposium on Human Impact and Geological Heritage. Excursion Guide and Abstracts (Raukas, A. \& Kukk, H., eds), pp. 115-117. Tallinn.

Sandgren, P., Subetto, D. A., Berglund, B. E., Davydova, N. N. \& Savelieva, L. A. 2004. MidHolocene Littorina Sea transgressions based on stratigraphic studies in coastal lakes of NW Russia. GFF, 126, 363-380.

Seppä, H., Tikkanen, M. \& Shemeika, P. 2000. Late-Holocene shore displacement of the Finnish south coast: diatom, litho- and chemostratigraphic evidence from three isolation basins. Boreas, 29, 219-231.

Stuiver, M., \& Reimer, P. J. 1993. Extended ${ }^{14} \mathrm{C}$ database and revised CALIB radiocarbon calibration program. Radiocarbon, 35, 215-230.

Svensson, N.-O. 1989. Late Weichselian and Early Holocene shore displacement in the central Baltic, based on stratigraphical and morphological records from eastern Småland and Gotland, Sweden. LUNDQUA Thesis, 25.

Thomson, P. W. 1933. Ein von Ancylusstrandbildungen bedecktes Torflager bei Jelgimägi. Beitr. Kunde Est-, Liv- und Kurlands, 18, 176-177.

Thomson, P. W. 1936. Esialgne teade Vääna Litoriinalõuka kohta. Eesti Loodus, 4, 161-162.

Thomson, P. W. 1937. Narva diatomiit. Eesti Loodus, 5, 214-216.

Veber, K. 1950. Maardu ümbruse geoloogiast. Tartu (unpublished diploma project at the Institute of Geology, University of Tartu).

Veski, S. 1998. Vegetation history, human impact and palaeogeography of West Estonia. Pollen analytical studies of lake and bog sediments. STRIAE, $\mathbf{3 8}$.

Veski, S., Heinsalu, A., Klassen, V., Kriiska, A., Lõugas, L., Poska, A. \& Saluäär, U. 2005. Early Holocene coastal settlements and palaeoenvironment on the shore of the Baltic Sea at Pärnu, southwestern Estonia. Quat. Int., 130, 75-85.

Wohlfarth, B., Possnert, G. \& Skog, G. 1998. Pitfalls in the AMS radiocarbon-dating of terrestrial macrofossils. J. Quat. Sci., 13, 137-145.

\section{Holotseensed mattunud organogeensed setted Eestis}

\section{Leili Saarse, Jüri Vassiljev, Avo Miidel ja Eve Niinemets}

On esitatud holotseensete mattunud setete andmebaas, mis sisaldab leiukohtade loendit, koordinaate, lasumite kõrgusi, ${ }^{14} \mathrm{C}$ dateeringuid, analüüsitud materjali nimetust ja viiteid allikmaterjalidele. Kokku on andmeid 85 leiukoha kohta. Radiosüsiniku dateeringute põhjal on väidetud, et Antsülusjärve transgressioon algas umbes $9500{ }^{14} \mathrm{C}$ aastat tagasi (10 $800 \mathrm{cal} \mathrm{BP}$ ) ja kulmineerus $200-300$ aastat hiljem, millele järgnes suhteliselt kiire regressioon, mis maakoore kiirema kerke alal ulatus kuni $30 \mathrm{~m}$. Mattunud setetes leiduv rohke männi õietolm oli peamiseks põhjuseks, miks Antsülusjärve transgressiooni Eestis loeti varem boreaalseks, ligi 1000 aastat nooremaks. Seni on Eestist andmeid vaid ühe Litoriinamere transgressiooni kohta. Litoriinamere transgressioon algas $7500-7000{ }^{14} \mathrm{C}$ aastat tagasi (8300-7800 cal BP) ja kulmineerus varem maakoore kiirema kerkega aladel, olles seega eriaegne. On esitatud Antsülusjärve ning Litoriinamere rannajoone modelleeritud isobaasjooned ja vastavate mattunud setete pealispindade korrelatsioon. 


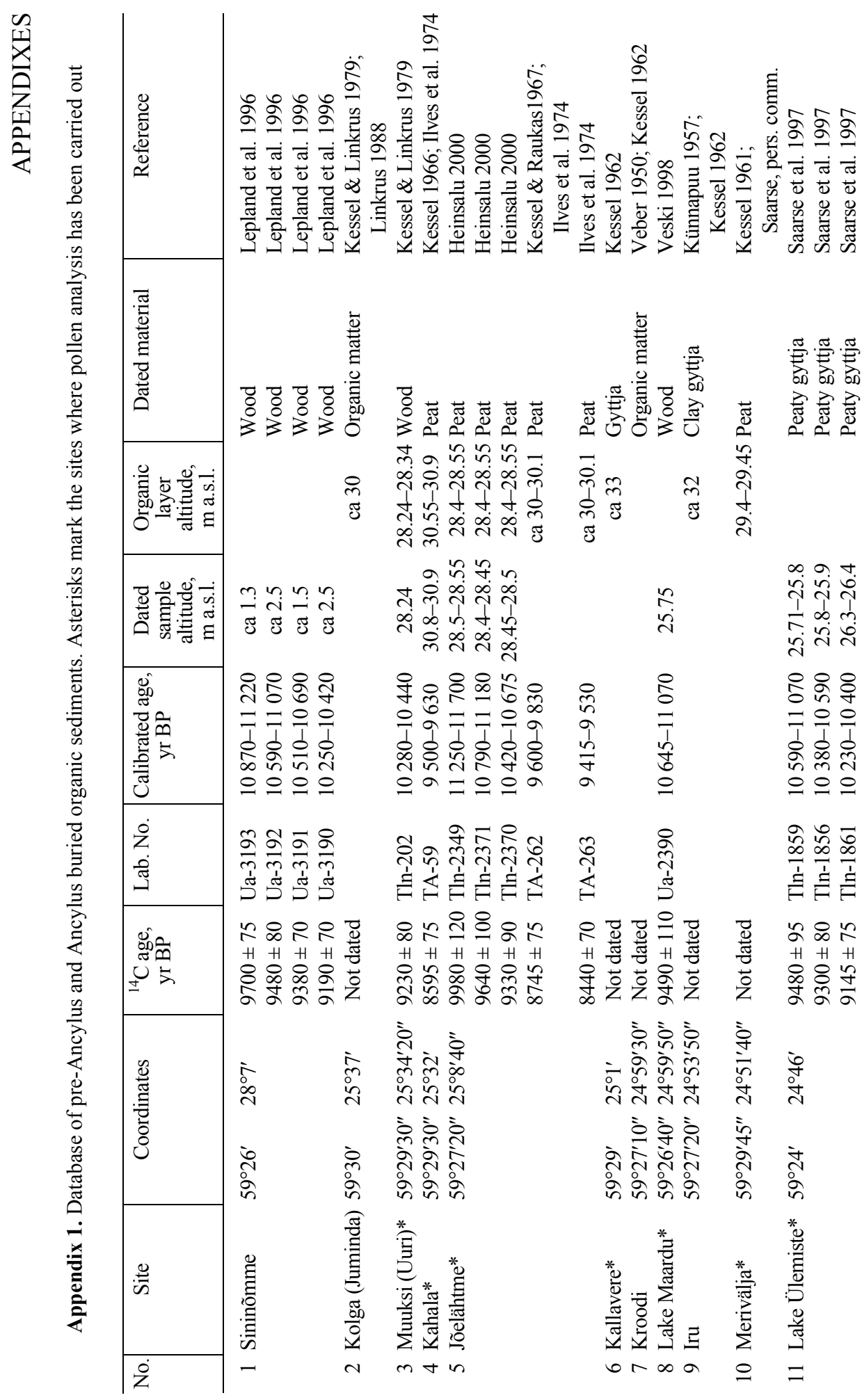




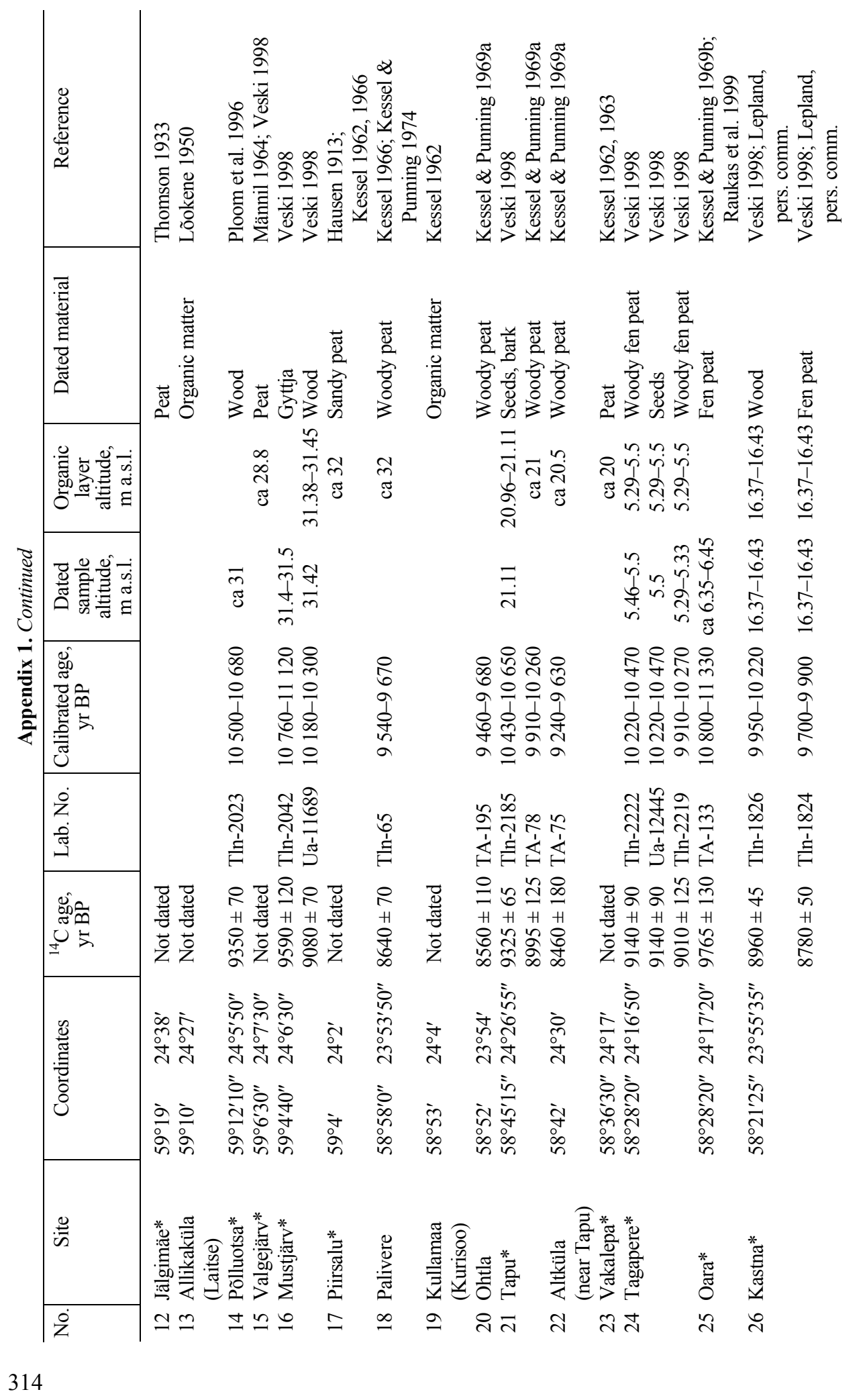




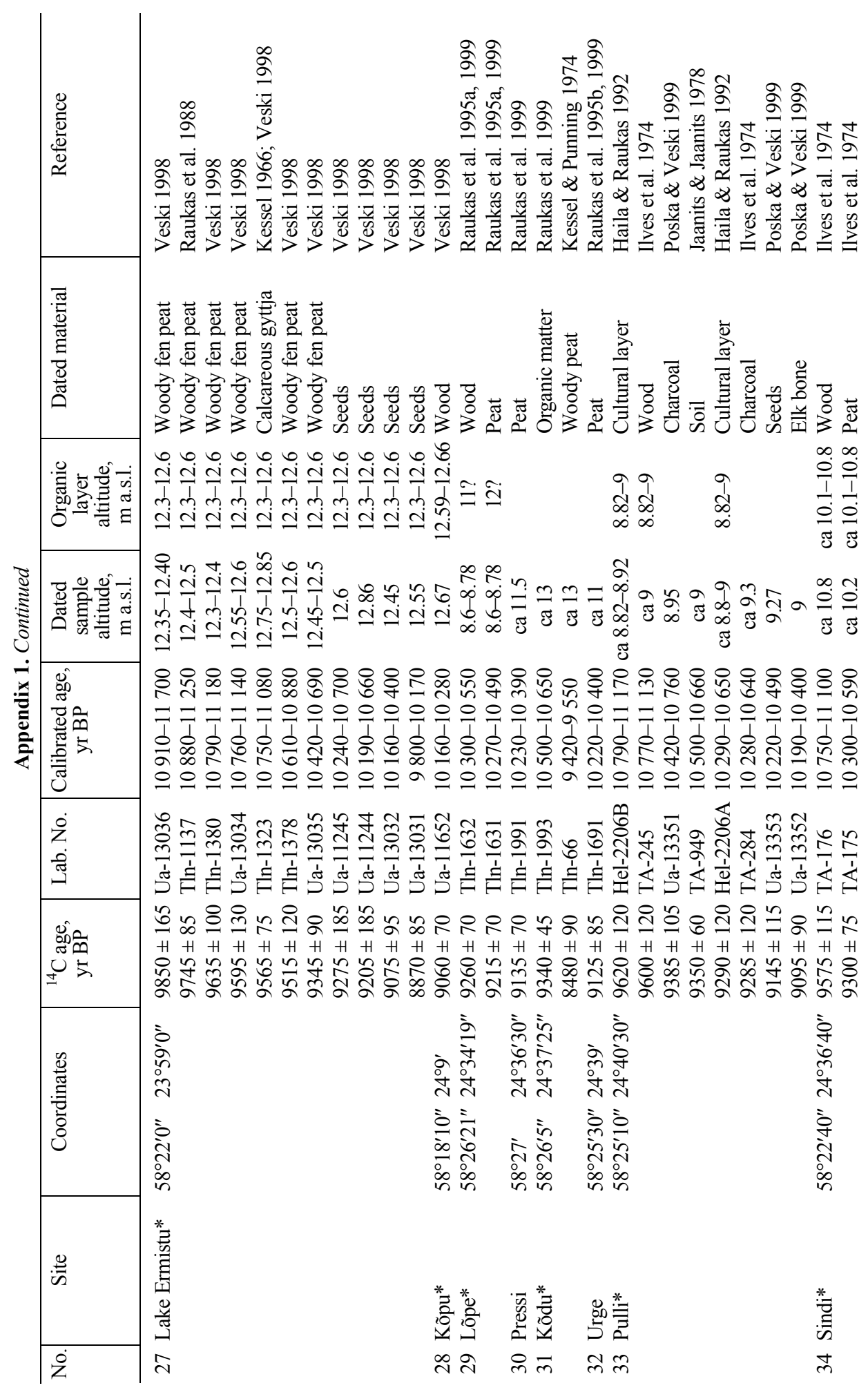




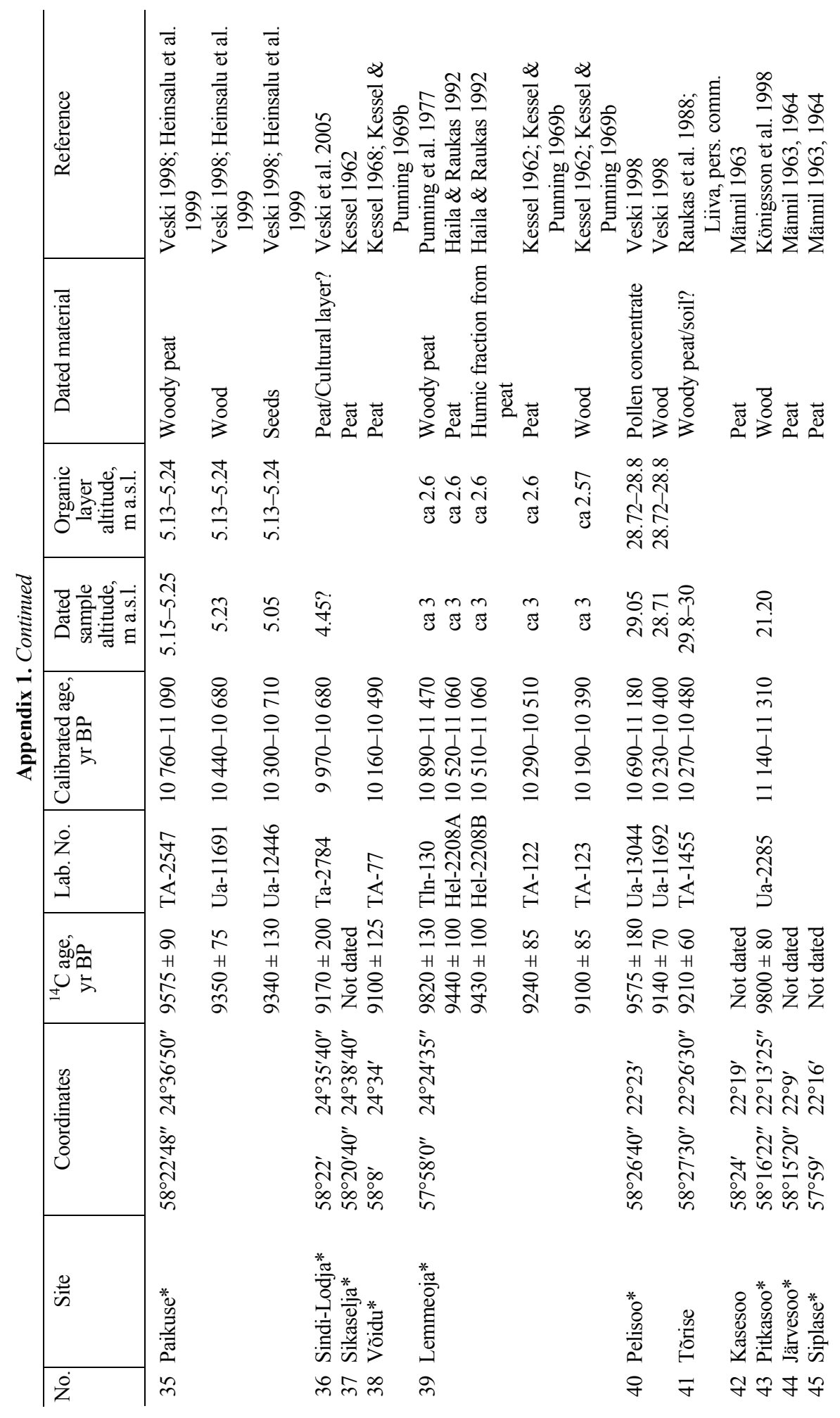




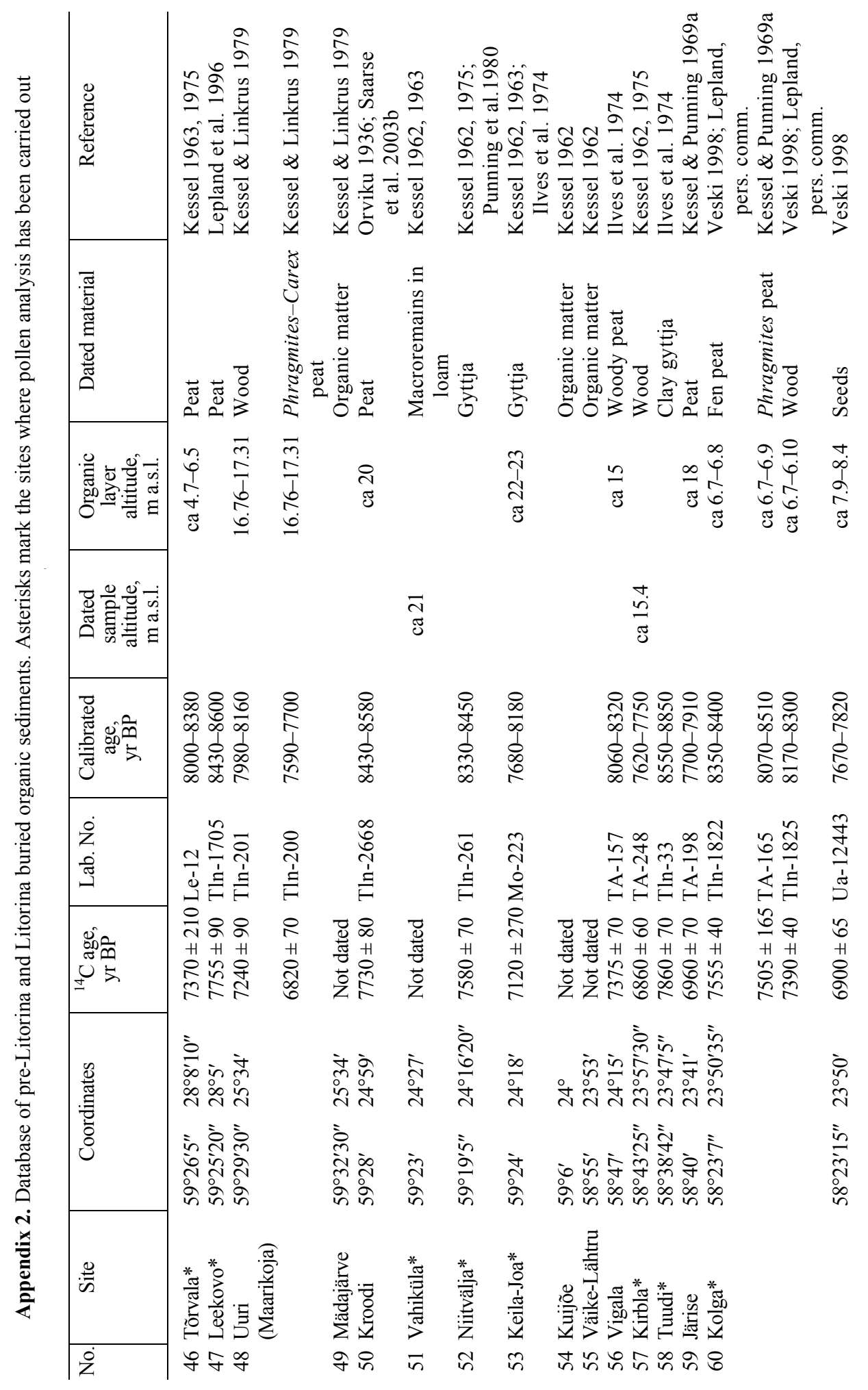




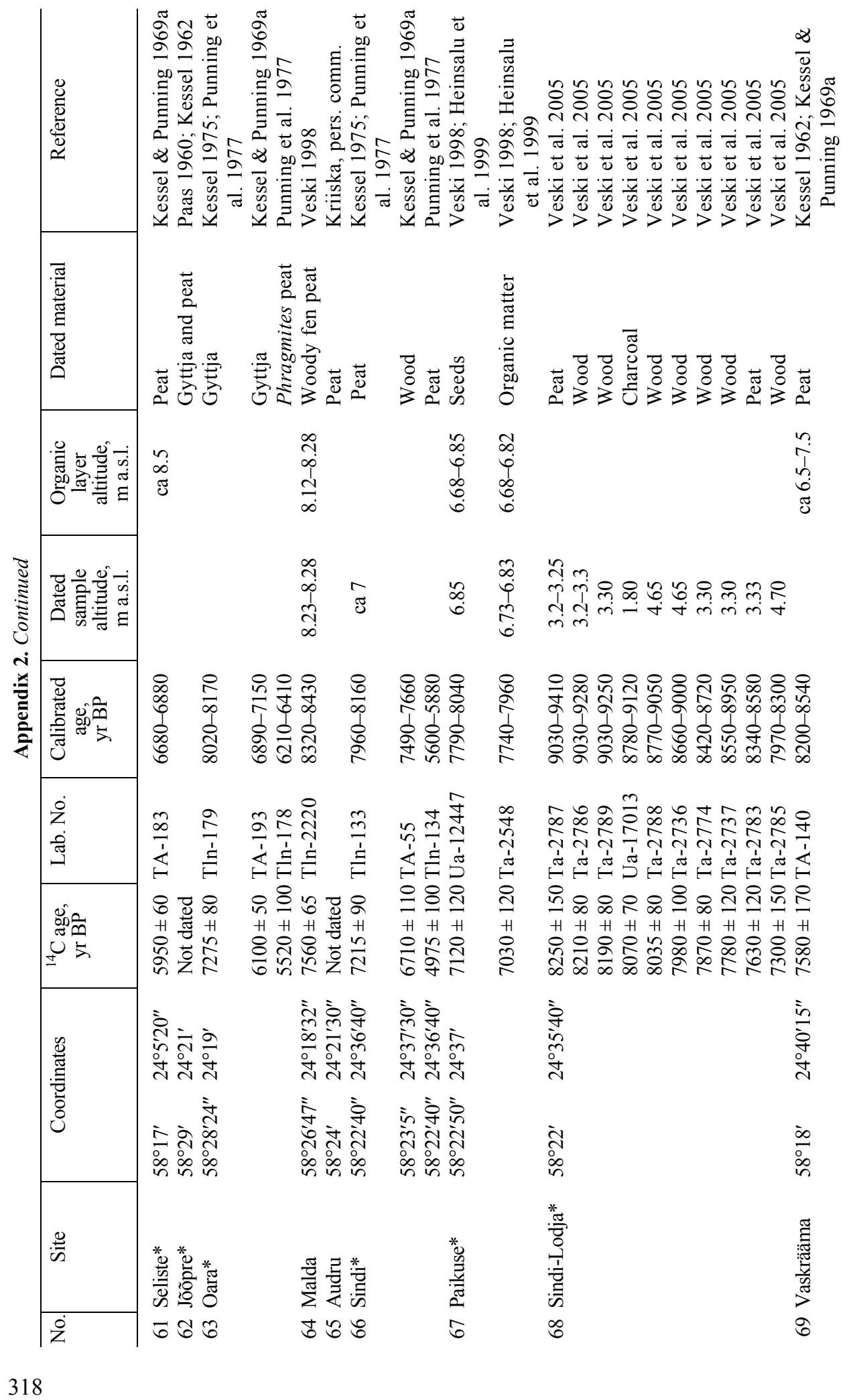




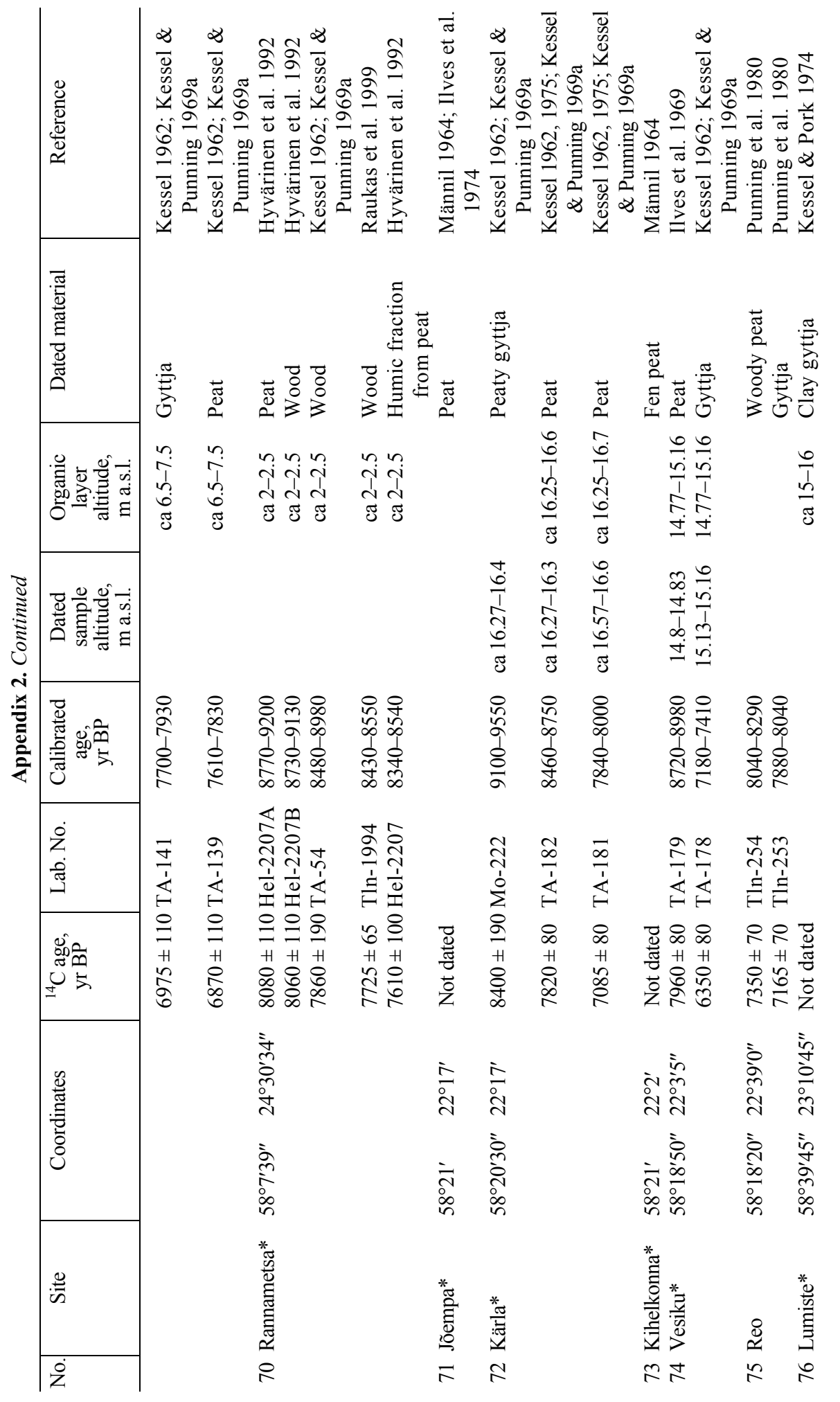




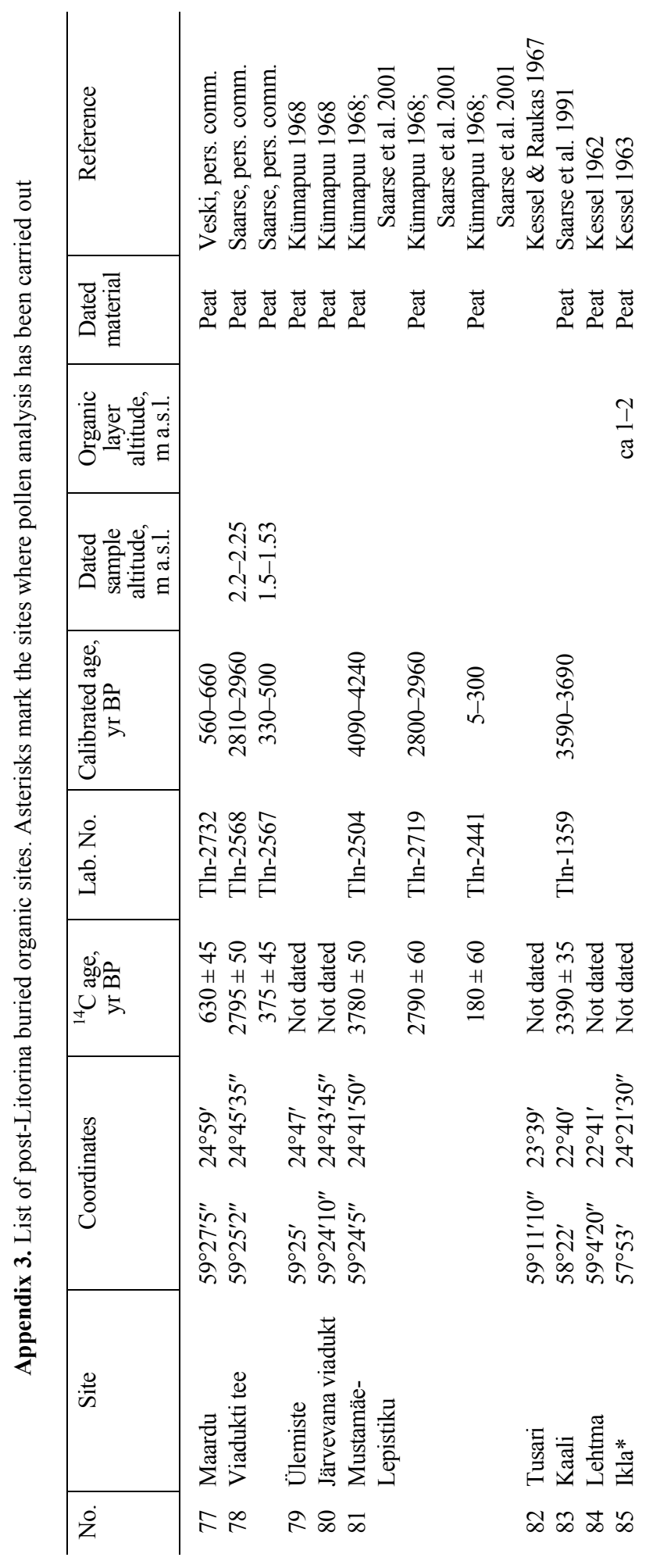

